\title{
Choosing when and how to die: Are we ready to perform therapeutic homicide?
}

\section{Ken Flegel MDCM MSc, John Fletcher MB BChir MPH}

$\mathrm{T}$ he Dying with Dignity commission of the Quebec National Assembly has issued its report after two years of public hearings, consultations with experts and visits to countries where there is now some experience with a range of options on ways of dying. ${ }^{1}$ The commission and the Charest government deserve equal praise for their thoughtful report and their courage in addressing this controversial topic. The principal theme of the report holds that palliative care has come of age and is adequate to meet the needs of most dying people; however, it is underprovided, particularly in remote and rural areas. ${ }^{2}$ A second important theme concerns "l'aide médicale à mourir" - medical assistance to die. On this subject, the report calls for a change in thinking, arguing that there will still be cases where suffering is great, irreversible and unrelievable, such that the only option is actively helping a person to die.

The recommendation is based on two legal considerations. First, the civil code recognizes the right of adult patients to make medical decisions concerning their care, even if refusing or stopping treatment may result in their death. Second, both the Quebec and Canadian charters of rights and freedoms enshrine the rights to personal dignity and integrity. These rights imply a respect for self-determination and a person's physical and psychological well-being. These are powerful arguments and suggest that an individual should be able to make life's important decisions in a free and unconditional way, including deciding when the struggle to stay alive should end. However, this line of reasoning only supports an individual's right to end his or her own life.

Proponents of "dying with medical assistance" must argue that a patient's rights invoke a corresponding medical duty to provide the means if a patient cannot, and it follows that this should be done in a safe and expert way. Hence, the act of assisting death would need to move from the context of being criminal to being part of the continuum of end-of-life care.

Many physicians and patients will find this a shocking prospect to consider. If their views are to prevail, they will need to argue why there should be limits to a person's autonomy. Human dignity may imply certain rights and freedoms, but conflicts among people's rights are hard to resolve. Frail, dependent patients often feel a burden to their families or caregivers, and the unspoken possibility of a quick resolution to their predicament may complicate an already stressful situation. Removing the legal barrier to ending another's life may ensure the selfdignity of those who wish to die, but may distress and remove the self-dignity of more people who wish to live.

Others will welcome this report as heralding a needed change in the way we perceive life and its ending. They will need to argue why patient autonomy trumps other considerations and why we should prepare to embrace euthanasia as routine. Proponents of euthanasia cannot assume that the practice will be restricted to extreme cases of untreatable suffering; they should be prepared to accept the implications of unrestricted choice, or a patient's "right to die." For example, in Belgium, where euthanasia has been legal since $2002,{ }^{3}$ half of all nonsudden deaths are the result of some decision to hasten the end of life; $4 \%$ of these deaths are defined as euthanasia, and $11 \%$ involve continuous deep sedation or rendering the person unconscious until he or she dies. ${ }^{3}$

If Quebec chooses to proceed with the report's recommendations, those who disagree will have to acknowledge that society's values have become more pluralistic. However, any change in the law must safeguard both health care workers and patients from possible abuses in its application. ${ }^{4}$

Public consultation in Quebec is only the first step. A change to the criminal code will need more national dialogue and action from federal lawmakers. Change should not be the result of one provincial Supreme Court decision (www.courts.gov.bc.ca/jdb -txt/SC/12/08/2012BCSC0886.htm). Issues such as who is expert at providing this new option, how it will be provided, and how to assist patients who do not fit the criteria or families who disagree with the patient's choice will be debated in a brave new future.

The ethics of euthanasia are a familiar debate in Canada; one that may have been theoretical until recently, because of the tacit assumption that doctors do not kill people. In Quebec, the debate is moving from theory toward practice. Which way will legislation go? Will the rest of Canada follow? Those who care about the answers to these questions must speak up now, and with conviction.

\section{References}

1. Mourir dans la dignité [report]. Québec (QC): Assemblée Nationale Québec 2012. Available: www.assnat.qc.ca/fr/actualites-salle-presse/nouvelle/actualite-25939.htm (accessed 2012 Jun. 12).

2. Parliamentary Committee on Palliative and Compassionate Care. Not to be forgotten: care of vulnerable Canadians. Ottawa (ON): The Committee; 2011. Available: http://pcpcc-cpspsc.com/wp-content/uploads/2011/11/ReportEN.pdf (accessed 2012 Apr. 1).

3. Van den Block L, Deschepper R, Bilsen J. Euthanasia and other end-of-life decisions: a mortality follow-back study in Belgium. BMC Public Health 2009;9:79.

4. Inghelbrecht E, Bilsen J, Mortier F, et al. The role of nurses in physician-assisted deaths in Belgium. CMAJ 2010;182:905-10.

Competing interests: See www.cmaj.ca/site/misc/cmaj_staff.xhtml

Affiliations: See www.cmaj.ca/site/misc/cmaj_staff.xhtml

Correspondence to: $C M A J$ editor, pubs@cmaj.ca

CMAJ 2012. DOI:10.1503/cmaj.120961 